\title{
Performance, digestibility and carcass characteristics of feedlot dairy steers fed diets with different urea levels
}

[Desempenho, digestibilidade e características de carcaça de novilhos mestiços leiteiros em confinamento alimentados com diferentes níveis de uréia na dieta]

\author{
K.A. Magalhães, S.C.Valadares Filho*, P.V.R. Paulino, M.F. Paulino, R.F.D. Valadares \\ Departamento de Zootecnia - UFV \\ Avenida P.H. Rolfs, s/n \\ 36570-000 - Viçosa, MG
}

\begin{abstract}
The effects of urea levels on feed intake, digestibility and carcass traits of 27 confined cross bred steers weighing $303.25 \pm 60.8 \mathrm{~kg}$, were evaluated. After weighing, castrating, vaccinating and a period of seven days, three steers were slaughtered at the beginning of the experiment and the remaining 24 were allotted in a completely randomized design to four isonitogenous experimental diets ( $12 \%$ of crude protein) and increasing level of urea on the dry matter-basis $(0.0 ; 0.65 ; 1.30$ and $1.65 \%)$ to replace soybean meal, so that the final content of the experimental diets were approximately $22,37,50$ and $63 \%$ of crude protein in the form of NPN. Corn and elephant grass silages were supplied at a 70:30 ratio and the total diet had a 65:35, forage: concentrate ratio on a DM-basis. The urea level did not affect nutrient intake, except for rumen degradable protein (RDP) and total digestible nutrients (TDN) linearly increased in function of diet urea level. The nutrient digestibilities linearly increased except for ether extract and non fiber carbohydrate (NFC). A quadratic effect of diet urea level on daily weight gain and no effect of urea level on carcass traits were observed. Urea can totally replace soybean meal in diets for confined crossed dairy steers allowing gains of $1 \mathrm{~kg} /$ day. Urea can enhance nutrient digestibility of diets.
\end{abstract}

Keywords: feedlot, carcass, intake, digestibility, non-protein nitrogen

\section{RESUMO}

Foram avaliados os efeitos dos níveis de uréia sobre o consumo, digestibilidade e características da carcaça de 27 novilhos $(303,25 \pm 60,80)$ confinados. Três animais foram abatidos no início do experimento e os 24 restantes foram distribuídos em delineamento inteiramente ao acaso em quatro tratamentos: 0; 0,65; 1,30 e 1,95\% de uréia na MS total da dieta, em substituição ao farelo de soja. A dieta final continha em torno de 22, 37, 50 e 63\% da PB na forma de compostos nitrogenados nãoprotéicos. Como volumoso foi utilizada uma mistura de $65 \%$ de silagem de milho e silagem de capimelefante na proporção 70:30, respectivamente. O consumo dos nutrientes não foi afetado pelos tratamentos, com exceção para o consumo de PDR e NDT que aumentaram linearmente. As digestibilidades dos nutrientes apresentaram comportamento linear crescente com exceção das digestibilidades do EE e CNF. Com relação ao desempenho dos animais, houve efeito quadrático dos tratamentos sobre o GMD. Não foi verificado nenhum efeito sobre as características de carcaça avaliadas. A uréia pode substituir completamente o farelo de soja na dieta de novilhos mestiços leiteiros em confinamento, permitindo ganhos de peso próximos a $1 \mathrm{~kg} /$ dia. O uso de uréia na dieta pode melhorar a digestibilidade dos nutrientes.

Palavras-chave: novilho, carcaça, consumo, digestibilidade, nitrogênio não-protéico

Recebido em 19 de outubro de 2004

Aceito em 17 de janeiro de 2006

*Corresponding author (autor para correspondência)

E-mail: scvfilho@ufv.br 


\section{INTRODUCTION}

The increasing demand for consistently high quality beef has caused changes in Brazilian cattle-raising. Nutritional management is one of the main factors in beef cattle production and adoption of feedlots as the major feeding strategy for the finishing phase in Brazil, has allowed an increase in productivity of beef cattle finishing. Since feed costs accounts for most of the costs of the feed out, producers and researchers have examined feedstuffs that meet the animal nutrient needs.

The protein fractions in cattle feeds are important because their relative cost. Thus research has focused on partial or total substitution of true protein sources by non-protein nitrogen (NPN). Urea has been the most widely used NPN compound in cattle diets because of its low cost per nitrogen unit, market availability, easy of use (Santos et al., 2001) and because it does not decrease yield or cause health problems in the animals (Huber, 1984).

The degree to which diets supplemented with urea are able to support adequate weight gains in feedlot steers has been inconsistent, requiring more studies to realize the quantity of urea that could be used. The recommendation for substitution levels traditionally adopted by most researchers is that the NPN can substitute up to $33 \%$ of protein nitrogen in diets of most ruminants (Velloso, 1984). It has also been suggested that the quantity of urea is limited to $1.0 \%$ of the total DM (Haddad, 1984).

Urea use in ruminant diets is limited because of low palatability, segregation when mixed with other feeds and toxicity at higher doses. However, several experiments with urea levels higher than the limits recommended have shown that there are no negative effects on the health of the animals (Hussein and Berger, 1995; Shain et al., 1998). However, the maximum level of urea inclusion before negative effects on performance has not yet been demonstrated.

The objective of this study was to investigate nutrient intake and digestibility as well as carcass characteristics of feedlot dairy steers fed diets with different urea levels.

\section{MATERIAL AND METHODS}

Twenty-seven crossbred dairy steers (303.25kg \pm 60.80$)$ with predominantly Holstein breeding were used. Twenty-four animals were assigned to four treatments in a completely randomized design with six steers per treatment. The study lasted 84 days in three periods of 28 days, in which the steers were placed in individual pens with clean drinking water always available, after weighing, castrating, vaccinating and previous adaptation to the diets, for a period of seven days. After this period, the three steers not assigned were slaughtered to serve as the reference group.

The four experimental diets were isonitrogenous $(12 \%$ of crude protein (CP)) with increasing levels of urea $(0 ; 0.65 ; 1.30$ and $1.95 \%$ on a dry matter (DM) - basis)), to replace soybean meal so that the final diet contained approximately 22 , 37,50 and $63 \%$ of CP in the form of NPN. The forage supplied was corn and elephant grass silage, at a DM ratio of 70:30, respectively, and the total diet had a forage: concentrate ratio of 65:35 on a DM - basis. The ingredient and chemical compositions of the experimental diets are in Table 1.

The diets were mixed manually for the entire study and offered once daily to allow approximately $10 \%$ of orts. Amounts of feed offered and refused were recorded daily by individual steer. Daily samples were grouped in weekly samples which represented the samples for each 28-day-period.

The steers were weighed at the beginning of the experiment and 28 day intervals, after fasting of 16 hours, to measure the average daily gain (ADG). All steers were slaughtered at the end of the experiment and the final live weight (LW) was recorded immediately prior the slaughter. The gastrointestinal tract of each animal was emptied, washed and weighed together with the organs and summed to the other parts of the body (carcass, head, skin, tail, hooves and blood) to determine the empty body weight (EBW). The ratio obtained between the EBW and $\mathrm{LW}$ of the reference group was used to estimate the initial EBW of the other steers. 
Table 1. Ingredient and chemical composition of the experimental diets for dairy steers

\begin{tabular}{|c|c|c|c|c|}
\hline & \multicolumn{4}{|c|}{ Treatment (\% urea level) } \\
\hline & 0 & 0.65 & 1.30 & 1.95 \\
\hline \multicolumn{5}{|l|}{ Ingredient $\left(\% \mathrm{DM}^{\mathrm{b}}\right)$} \\
\hline Corn silage & 45.50 & 45.50 & 45.50 & 45.50 \\
\hline Elephant grass silage & 19.50 & 19.50 & 19.50 & 19.50 \\
\hline Ground sorghum grain & 21.60 & 25.11 & 28.63 & 32.17 \\
\hline Soybean meal & 12.71 & 8.49 & 4.25 & - \\
\hline Urea & - & 0.65 & 1.30 & 1.95 \\
\hline Ammonia sulfate & - & 0.06 & 0.13 & 0.19 \\
\hline Salt & 0.25 & 0.25 & 0.25 & 0.25 \\
\hline Dicalcium phosphate & 0.32 & 0.32 & 0.32 & 0.32 \\
\hline Limestone & 0.10 & 0.10 & 0.10 & 0.10 \\
\hline Mineral Premix $^{a}$ & 0.02 & 0.02 & 0.02 & 0.02 \\
\hline \multicolumn{5}{|l|}{ Chemical composition } \\
\hline Dry matter & 49.46 & 49.47 & 49.46 & 49.45 \\
\hline Organic matter, \%DM & 92.82 & 92.33 & 91.85 & 91.36 \\
\hline Crude protein, \% DM & 11.78 & 12.04 & 12.30 & 12.54 \\
\hline RUN, $\% \mathrm{CP}^{C}$ & 67.06 & 71.35 & 75.28 & 79.27 \\
\hline $\mathrm{NPN}, \% \mathrm{CP}^{C}$ & 22.94 & 37.07 & 50.63 & 63.71 \\
\hline Ether extract, \%DM & 2.40 & 2.44 & 2.49 & 2.40 \\
\hline NDFap, $\% D M$ & 41.33 & 41.06 & 40.77 & 40.49 \\
\hline $\mathrm{NFC}, \% \mathrm{DM}$ & 37.99 & 39.36 & 40.74 & 42.12 \\
\hline Lignin, \%DM & 5.73 & 5.68 & 5.50 & 5.60 \\
\hline
\end{tabular}

The carcass of each steer was divided into halves and weighed to determine the carcass gain as well as the dressing proportion. The length of the right carcass was also measured. The transversal area of the Longissimus dorsi muscle (rib-eye area) at the $12^{\text {th }}$ rib and the subcutaneous fat thickness (grade fat) were measured on the left half of the carcass.

The samples were pre-dried in a $65^{\circ} \mathrm{C}$ forced air oven and ground to pass a $1 \mathrm{~mm}$ sieve in a Wiley mill for later laboratory analyses. The contents of $\mathrm{DM}$, organic matter $(\mathrm{OM})$, nitrogen $(\mathrm{N})$, ether extract (EE), ash and lignin were determined as described by Silva and Queiroz (2002). Neutral detergent insoluble nitrogen (NDIN) and acid detergent insoluble nitrogen (ADIN) were determined according to Van Soest et al. (1991) and non-protein nitrogen (NPN), according to Licitra et al. (1996).

Neutral detergent fiber (NDF) and acid detergent fiber (ADF) contents were determined according to the micro-NDF method described by Pell and Schofield (1993). The NDF was corrected for ash and protein (NDFap) in the feed samples, orts and feces to calculate the NDF and non-fiber carbohydrate (NFC) digestibilities.
Total carbohydrates $(\mathrm{CHO})$ were calculated as: according to Sniffen et al. (1992).

Because of the presence of urea in the diets, the NFC was calculated as proposed by Hall (2000):

$N F C=100-[(\% C P-\% C P$ from urea $+\%$ urea $)$ $+\%$ NDFap $+\% E E+\% a s h]$.

Total digestible nutrients (TDN) were calculated from the following summative equation:

$T D N=d C P+d N D F a p+d N F C+2,25 x d E E$,

where $d C P, d N D F a p, d N F C$ and $d E E$ indicate, respectively, digestible $\mathrm{CP}$, digestible NDFap, digestible NFC and digestible EE.

The contents of rumen-degradable protein (RDP) were calculated according to the NCR (Nutrient..., 2001) recommendation by the equation:

$R D P=A+B * k d /(k d+k p)$,

where A, B, kd and $\mathrm{kp}$ indicate, respectively, the water soluble fraction, the water-insoluble and 
potentially degradable fraction, rate of $\mathrm{B}$ fraction degradation and the rate of passage of $\mathrm{CP}$ through the rumen. The values A (\%), B (\%) and $\mathrm{kd}(5 \% / \mathrm{h})$ adopted were $54.72 ; 36.0$ and 6.68 for corn silage; 22.8, 44.04 and 3.72 for elephant grass silage; $18.21 ; 78.59$ and 9.9 for soybean meal and 29.13; 60.8 and 5.0 for sorghum (Valadares Filho et al., 2002), while the kp values were estimated according to the NRC (Nutrient..., 2001) equations resulting in $5 \% / \mathrm{h}$ for all the ingredients in the diet.

In the second experimental period, feces were collected to determine apparent nutrient digestibility. Feces were collected directly from the ground immediately after defection at two times (morning and afternoon) on consecutive days. The feces samples were homogenized, placed in aluminum dishes and pre-dried in a forced air oven at $65^{\circ} \mathrm{C}$ for 72 hours, ground to pass a $1 \mathrm{~mm}$ sieve in a Wiley mill and grouped proportionally, performing the samples for each steer.

Indigestible acid detergent fiber (iADF) was used to estimate fecal DM output, as proposed by
Cochran et al. (1986). However, rumen incubation in Ankom (F57 filter bag) was used for 144 hours, instead of the in vitro digestibility suggested in the original procedure. Samples of orts, feces and ingredients from the diets were incubated in the rumen. The material remaining from the incubation was boiled in acid detergent for one hour, and the residue of this analysis was considered $\mathrm{iADF}$.

The study was analyzed as a completely randomized experiment using the Minitab $12 .{ }^{1}$ Linear and quadratic effects of urea levels were tested at $\mathrm{P}<0.05$.

\section{RESULTS}

No differences occurred among treatments for DM, OM, CP, EE, NDF and NFC intake (Table 2). NDF intake averaged $1.1 \%$ of the $\mathrm{LW}$, a value close to that suggested by Mertens (1994) as being at which optimum DM intake occurs in dairy cows.

Table 2. Nutrient intake by dairy steers fed on diets with different urea levels

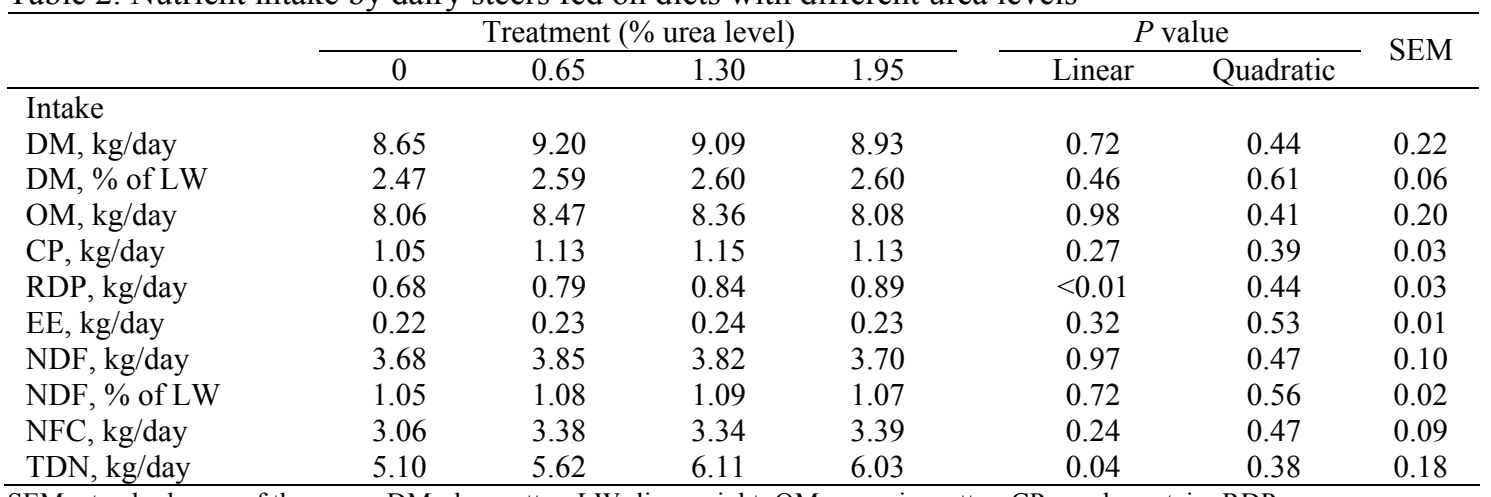

$\mathrm{SEM}=$ standard error of the mean. $\mathrm{DM}=$ dry matter; $\mathrm{LW}=$ live weight; $\mathrm{OM}=$ organic matter; $\mathrm{CP}=$ crude protein; $\mathrm{RDP}=$ rumen degradable protein; $\mathrm{EE}=$ ether extract; $\mathrm{NDF}=$ neutral detergent fiber; $\mathrm{NFC}=$ non-fiber carbohydrate; TDN=total digestible nutrients .

The RDP intake increased linearly with the increase in the levels of urea and consequently $82.4,95.8,101.9$ and $107.9 \%$ of its requirements were met, since the total estimated RDP need, according to the NRC (Nutrient...,1996), was $824.7 \mathrm{~g} /$ day. The total CP need was $861.2 \mathrm{~g} /$ day and as the average CP intake by the steers was $1.1 \mathrm{~kg} /$ day, it was concluded that $130 \%$ of the requirement proposed by the NRC (Nutrient...,2001) was met by the diets. Also the TDN intake increased linearly $(\mathrm{P}<0.05)$.

${ }^{1}$ Minitab Inc, State College, PA, USA 
Nutrient digestibilities increased linearly $(\mathrm{P}<0.05)$, except for the EE and NFC digestibilities (Table 3) which presented mean values of 79.9 and $77.2 \%$ respectively. TDN values also increased linearly when urea replaced the soybean meal in the diets. That can be due to the increase on digestibility of DM, NDFap and CP. It should also be pointed out that with the inclusion of urea in the diets, soybean meal was removed and sorghum, a more energetic ingredient was added, so that would justify the increase in the TDN values.

No linear effect of the urea levels on any of the performance variables studied was found (Table $4)$, except a quadratic effect on $\mathrm{ADG}(\mathrm{P}<0.05)$ with minimum gains at the lowest and highest urea inclusion levels. The average ratio obtained for the EBW estimate from the animals' LW was LW $x$ 0.8464, a lower value than that recommended by NRC (Nutrient..., 1996) of 0.891 . However, this value is close to that of 0.8309 obtained by Silva et al. (2002), who compiled data in the Brazilian literature for crossbred dairy steers.

No treatment influence on any carcass characteristic was observed (Table 5). The dressing proportion averaged 52.1\%. Mean values of $1.89 \mathrm{~mm}$ and $67.73 \mathrm{~cm}^{2}$ were detected for the subcutaneous fat thickness (grade fat) and the rib-eye area, respectively.

Table 3. Nutrient digestibility and TDN values by dairy steers fed on diets with different urea levels

\begin{tabular}{lcccccccc} 
& \multicolumn{3}{c}{ Treatment (\% urea level) } & & \multicolumn{3}{c}{$P$ value } & \multirow{2}{*}{ SEM } \\
\cline { 2 - 4 } & 0 & 0.65 & 1.30 & 1.95 & & Linear & Quadratic & \\
\hline Digestibility (\%) & & & & & & & & \\
DM & 65.32 & 65.70 & 69.38 & 69.17 & & $<01$ & 0.80 & 0.67 \\
OM & 65.29 & 65.37 & 68.63 & 68.50 & & 0.02 & 0.93 & 0.64 \\
CP & 59.37 & 61.73 & 65.81 & 67.73 & & $<0.01$ & 0.88 & 0.95 \\
EE & 77.36 & 80.19 & 81.66 & 80.43 & & 0.10 & 0.15 & 0.73 \\
NDFap & 43.80 & 45.11 & 49.91 & 50.81 & & 0.008 & 0.92 & 1.15 \\
NFC & 75.16 & 74.65 & 81.01 & 78.11 & & 0.17 & 0.63 & 1.24 \\
TDN (\% of DM) & 58.88 & 60.80 & 67.17 & 67.71 & & $<0.01$ & 0.66 & 1.07 \\
\hline
\end{tabular}

$\mathrm{SEM}=$ standard error of the mean. $\mathrm{DM}=$ dry matter; $\mathrm{OM}=$ organic matter; $\mathrm{CP}=$ crude protein; $\mathrm{EE}=$ ether extract; $\mathrm{NDF} a p=$ neutral detergent fiber corrected for ash and protein; $\mathrm{NFC}=$ non-fiber carbohydrate; $\mathrm{TDN}=$ total digestible nutrients.

Table 4. Performance of dairy steers fed on diets with different urea levels

\begin{tabular}{lccccccccc}
\hline & \multicolumn{3}{c}{ Treatment (\% Urea Levels) } & & \multicolumn{3}{c}{$P$ value } & \multirow{2}{*}{ SEM } \\
\cline { 2 - 4 } & 0 & 0.65 & 1.30 & 1.95 & & Linear & Quadratic & \\
\hline Final weight, kg & 397 & 409 & 406 & 396 & & 0.96 & 0.68 & 12.98 \\
ADG, kg/day & 1.13 & 1.24 & 1.23 & 1.10 & & 0.77 & 0.04 & 0.03 \\
EBW gain, kg/day & 1.21 & 1.25 & 1.28 & 1.08 & & 0.33 & 0.12 & 0.04 \\
Feed:gain ratio & 7.77 & 7.43 & 7.45 & 7.98 & & 0.74 & 0.32 & 0.21 \\
EBW/LW ratio & 85.89 & 84.20 & 84.61 & 83.86 & & 0.22 & 0.65 & 0.51 \\
\hline
\end{tabular}

$\mathrm{SEM}=$ standard error of the mean. $\mathrm{ADG}=$ average daily gain; $\mathrm{EBW}=$ empty body weight; $\mathrm{LW}=$ live weight.

Table 5. Carcass characteristics of dairy steers fed on diets with different urea levels

\begin{tabular}{|c|c|c|c|c|c|c|c|}
\hline & \multicolumn{4}{|c|}{ Treatment (\% urea level) } & \multicolumn{2}{|c|}{$P$ value } & \multirow{2}{*}{ SEM } \\
\hline & 0 & 0.65 & 1.30 & 1.95 & Linear & Quadratic & \\
\hline \multicolumn{8}{|l|}{ Carcass characteristic } \\
\hline Dressing proportion & 52.55 & 52.64 & 52.00 & 51.21 & 0.30 & 0.66 & 0.49 \\
\hline Carcass length, $\mathrm{cm}$ & 127.0 & 128.0 & 128.0 & 126.0 & 0.88 & 0.65 & 0.01 \\
\hline Rib-eye area, $\mathrm{cm}^{2}$ & 64.32 & 67.15 & 74.60 & 64.87 & 0.66 & 0.17 & 2.21 \\
\hline Grade fat, $\mathrm{mm}$ & 1.50 & 2.23 & 1.90 & 1.93 & 0.55 & 0.33 & 0.17 \\
\hline
\end{tabular}

$\mathrm{SEM}=$ standard error of the mean. 


\section{DISCUSSION}

The inclusion of non-protein sources in ruminant diets, such as urea, that is totally soluble in the rumen environment, immediately meets ammonia requirements for growth microbial. If these $\mathrm{N}$ requirements are met, a positive effect is expected on the forage intake and digestibility (Griswold et al., 2003). Replacing all the soybean meal protein by urea, the RDP intake increased linearly (Table 2).

When determining the protein requirements of feedlot zebu steers with an initial LW of $270 \mathrm{~kg}$, Paulino (2002) concluded that as the LW of the steers increased, the need for rumenundegradable protein (RUP) decreased, enabling a greater participation of RDP to meet the total demands for CP. Therefore, finishing animals can be fed higher levels of NPN without harming performance, thereby contributing to cost reductions of the diet.

Knaus et al. (2001) and Restle et al. (2001) with Holstein cattle stated that use of urea (1.2 and $1.8 \%$ of the DM, respectively) did not affect DM intake. In an experiment with steers from four genetic groups, Rennó (2003) assessed urea levels similar to those in the present study $(0$; $0.65 ; 1.3$ and $1.9 \%$ in $\mathrm{DM})$ and did not observe any treatment effects on nutrient intake.

The use of urea at high levels in the diet can reduce DM intake because of its low palatability (Haddad, 1984). Wilson et al. (1975) supplied increasing levels of urea $(1.0 ; 1.65 ; 2.3$ and $3.0 \%$ in the total DM) to steers, either orally, or by direct infusion to the rumen, and ascertained that urea seemed to reduce intake when it was included in the diet at levels greater than $2.0 \%$ of total DM.

Although the DM, OM, CP and NDF intakes were not affected by the treatments, (Table 2), their digestibility increased linearly with the urea levels (Table 3 ). This can be partly attributed by meeting the ammonia requirements of the rumen microorganisms with the inclusion of RDP in the diets (Table 2) that favored higher DM digestibility. The linear increase in $\mathrm{CP}$ digestibility can be explained by the fact that urea is considered $100 \%$ digestible. Thus replacement of protein of soybean meal by urea improved the apparent digestibility of $\mathrm{CP}$ in the diet.

Rennó (2003) assessed urea levels similar to those in this study and reported a lack of effects of the treatments on the total digestibility of the nutrients, except for NFC that decreased linearly. However, Knaus et al. (2001), with Holstein steers, founded that the use of urea $(1.8 \%$ in the $\mathrm{DM})$ reduced digestibility of DM, OM and NFC. There is inconsistency in effects of use of urea on digestibility of nutrients in the diet.

Animal performance results obtained were expectable since, according to Mertens (1994), 60 to $90 \%$ of animal performance is a consequence of the DM intake and it was not affected by the treatments.

However, a quadratic effect of urea levels was observed on ADG, suggesting that urea level beyond $0.93 \%$ (first derivative of the quadratic regression) causes a reduction, consistently with the recommendation of using urea at no more than $1.0 \%$ on total DM (Haddad, 1984). Probably, higher energy costs involved with excretion of higher amount of ammonia produced when urea is used in the diet, would explain lower ADG observed in the animals fed with $1.95 \%$ of urea. In spite of that, an ADG of $1.08 \mathrm{~kg} /$ day (treatment with $1.95 \%$ of urea) is still very reasonable for the Brazilian beef cattle production systems. Actually, the net economic return for the animals fed diets with the high level of urea could surpass that in which the diet is formulated to achieve higher rates of gain. Therefore, maximum biological performance may not always correspond with maximum economical performance.

Shain et al. (1998), using increasing levels of urea $(0 ; 0.88 ; 1.34$ and $1.96 \%$ of $\mathrm{DM})$ in the diet of steers, did not found differences in weight gain and feed to gain ratio, but showed that the steers supplemented with urea in the diets had higher gains $(1.53 \mathrm{~kg} /$ day, on average) and were more efficient $(5.4 \%)$ than those not receiving urea.

However, Knaus et al. (2001) reported lower performance, especially $\mathrm{ADG}$, in steers fed urea compared to those that received true protein sources and the authors attributed this 
performance difference to an insufficiency of RUP in the diets that contained urea.

Subcutaneous fat thickness (grade fat) is one of the characteristics which has an impact on dressing proportion, because the lean meat dressing percent decreases with increases in the grade fat. Brazilian grade system of carcass enables carcasses with little fat ( 1 to $3 \mathrm{~mm})$ to be considered adequate (Cruz, 2000). The mean value in the present study was $1.89 \mathrm{~mm}$, consistent with Marquat (1964) who reported that there is an increase in the proportion of subcutaneous fat in the carcass of steers of dairy breeds after they reach an average of $454 \mathrm{~kg} \mathrm{LW}$. The animals in the present study did not reach this weight, being slaughtered with an average LW of $403 \mathrm{~kg}$.

Hussein and Berger (1995), in an experiment with Holstein steers, did not ascertain damage to the carcass characteristics of the animals when $50 \%$ of the soybean meal protein was replaced by urea. Shain et al. (1998) studied steers in feedlots fed diets with increasing levels of urea $(0 ; 0.88 ; 1.34$ and $1.96 \%$ in the DM) and did not detect differences in hot carcass weight or in the grade fat of the steers among treatments.

\section{CONCLUSIONS}

Under the conditions of this experiment, urea can completely replace soybean meal for feedlot dairy steers allowing ADG close to $1 \mathrm{~kg} /$ day. Using urea in the diet also resulted in improvement of nutrient digestibility.

\section{ACKNOWLEDGEMENTS}

The authors wish to acknowledge the collaborators of this research: M.O. PORTO, M.L. CHIZZOTTI e K. ANDREATTA.

\section{REFERENCES}

COCHRAN, R.C.; ADAMS, D.C.; WALLACE, J.D. et al. Predicting digestibility diets with internal markers: Evaluation of four potential markers. J. Anim. Sci., v.63, p.1476-1483, 1986.
CRUZ, G.M. Produção de carne bovina utilizando confinamento. In: SIMPÓSIO SOBRE MANEJO E NUTRIÇÃO DE GADO DE CORTE, 2000, Goiânia. Anais... Goiânia, 2000. p.91-106.

GRISWOLD, K.E.; APGAR, G.A.; BOUTON, J. Effects of urea infusion and ruminal degradable protein concentration on microbial growth, digestibility, and fermentation in continuous culture. J. Anim. Sci., v.81, p.329-336, 2003.

HADDAD, C.M. Uréia em suplementos alimentares. In: SIMPÓSIO SOBRE NUTRIÇÃO DE BOVINOS - Uréia para ruminantes, 2., 1984, Piracicaba. Anais... Piracicaba: FEALQ, 1984. p.119-141.

HALL, M.B. Calculation of non-structural carbohydrate content of feeds that contain nonprotein nitrogen. University of Florida, A25A32 (Bulletin 339, April), 2000.

HUBER, J.T. Uréia em nível de rúmen. In: SIMPÓSIO SOBRE NUTRIÇÃO DE BOVINOS - Uréia para ruminantes, 2., 1984, Piracicaba. Anais... Piracicaba: FEALQ, 1984. p.6-24.

HUSSEIN, H.S.; BERGER, L.L. Feedlot performance and carcass characteristics of Holstein steers as affected by source of dietary protein and level of ruminally protected lysine and methionine. J. Anim. Sci., v.73, p.3503-3509, 1995.

KNAUS, W.F.; BEERMANN, D.H.; GUIROY, P.J. et al. Optimization of rate and efficiency of dietary nitrogen utilization through the use of animal by-products and (or) urea and their effects on nutrient digestion in Holstein steers. $J$. Anim. Sci., v.79, p.753-760, 2001.

LICITRA, G.; HERNANDEZ, T.M.; VAN SOEST, P.J. Standardization of procedures for nitrogen fractionation of ruminant feeds. Anim. Feed Sci. Technol., v.57, p.347-358, 1996.

MARQUAT, W.R. Dairy beef in packing industry. J. Anim. Sci., v.47, p.1145-1149, 1964.

MERTENS, D.R. Regulation of forage intake. In: FAHEY Jr., G.C., (Ed.) Forage quality, evaluation and utilization. In: NATIONAL CONFERENCE ON FORAGE QUALITY, EVALUATION AND UTILIZATION. American Society of Agronomy, 1994. p.450493. 
NUTRIENT requirements of beef cattle. 7.ed. Washinton: NRC, 1996. 242p.

NUTRIENT requirements of dairy cattle. 7.ed. Washinton: NRC, 2001. 381p.

PAULINO, P.V.R. Exigências nutricionais e validação da seção $\mathrm{HH}$ para predição da composição corporal de zebuínos. 2002. 150f. Tese (Mestrado) - Departamento de Zootecnia, Universidade Federal de Viçosa, Viçosa, MG.

PELL, A.N.; SCHOFIELD, P. Computerized monitoring of gas production to measure forage digestion in vitro. J. Dairy Sci., v.76, p.10631073, 1993.

RENNÓ, L.N. Consumo, digestibilidade total e parcial, produção microbiana, parâmetros ruminais e excreções de uréia e creatinina em novilhos alimentados com dietas contendo quatro níveis de uréia ou dois de proteína. 2003. 252f. Tese (Doutorado) - Departamento de Zootecnia, Universidade Federal de Viçosa, Viçosa, MG.

RESTLE, J.; PASCOAL, L.L.; ROSA, J.R.P. et al. Effect of protein levels, via non-protein nitrogen, on the performance of early weaned beef calves. In: REUNIÃO ANUAL DA SOCIEDADE BRASILEIRA DE ZOOTECNIA, 38., 2001, Piracicaba. Anais... Piracicaba: SBZ, 2001. p.1371-1372.

SANTOS, G.T.; CAVALIERI, F.L.B.; MODESTO, E.C. Recentes avanços em nitrogênio não protéico na nutrição de vacas leiteiras. In: SINLEITE- SIMPÓSIO INTERNACIONAL EM BOVINOCULTURA DE LEITE - Novos conceitos em nutrição, 2. 2001, Lavras. Anais... Lavras: UFLA, 2001. p.199-228.

SHAIN, D.H.; STOCK, R.A.; KLOPFENSTEIN, T.J. et al. Effect of degradable intake protein level on finishing cattle performance and ruminal metabolism. J. Anim. Sci., v.76, p.242-248, 1998.

SILVA, D.J.; QUEIROZ, A.C. Análise de alimentos (Métodos químicos e biológicos). 3.ed. Viçosa: University Press, 2002. 235p.

SILVA, F.F.; VALADARES FILHO, S.C.; ÍTAVO, L.C.V. et al. Net and dietary energy, protein and macrominerals requirements of beef cattle in Brazil. Braz. J. Anim. Sci., v.31, p.776792, 2002.

SNIFFEN, C.J.; O'CONNOR, J.D.; VAN SOEST, P.J. et al. A net carbohydrate and protein system for evaluating cattle diets: II. Carbohydrate and protein availability. J. Anim. Sci., v.70, p.3562-3577, 1992.

VALADARES FILHO, S.C.; ROCHA JÚNIOR, V.R.; CAPPELLE, E.R. Tabelas brasileiras de composição de alimentos para bovinos. CQBAL 2.0. Viçosa: Universidade Federal de Viçosa. Suprema Gráfica Ltda, 2002. 297p.

VAN SOEST, P.J.; ROBERTSON, J.B.; LEWIS, B.A. Methods for dietary fiber, neutral detergent fiber, and nonstarch polyssacarides in relation to animal nutrition. J. Anim. Sci., v.74, p.35833597, 1991.

VELLOSO, L. Uréia em rações de engorda de bovinos. In: SIMPÓSIO SOBRE NUTRIÇÃO DE BOVINOS - Uréia para ruminantes, 2., 1984, Piracicaba. Anais... Piracicaba: FEALQ, 1984. p. 174-199.

WILSON, G.; MARTZ, F.A.; CAMPBELL, J.R. et al. Evaluation of factors responsible for reduced voluntary intake of urea diets for ruminants. J. Anim. Sci., v.41, p.1431-1437, 1975. 